\title{
Interrelations Between Odonto-Parodontal Affects of the First Permanent Molar and their Odontogenetic and Morfostructural Peculiarities
}

\author{
DANIELA ANISTOROAEI ${ }^{1}$, MADALINA NICOLETA MATEI ${ }^{2}$, MARIANA PACURAR ${ }^{3}$, ROXANA BUZATU ${ }^{4 *}$, ANCA PORUMB ${ }^{5}$, \\ CRISTIAN ROMANEC ${ }^{1}$ \\ ${ }^{1}$ Grigore T. Popa University of Medicine and Pharmacy lasi, Faculty of Dental Medecine, 16 Universitatii Str.,700115, Iasi, \\ Romania \\ 2Dunarea de J os University of Galati, Medicine and Pharmacy Faculty, Departament of Dentistry, 47 Domneasca Str., 800008, \\ Galati,Romania. \\ ${ }^{3}$ University of Medicine and Pharmacy Tg. Mures ,Faculty of Dental Medecine, Gh. Marinescu Str., 38, Targu Mures, 540139, \\ Romania \\ ${ }^{4}$ Victor Babes University of Medicine and Pharmacy Timisoara, Faculty of Dental Medecine 2 Eftimie Murgu Sq., 300041,Timisoara, \\ Romania \\ EUniversity of Oradea, Faculty of Medicine and Pharmacy, 10,1 Decembrie Sq.,Oradea, Romania
}

\begin{abstract}
The permanent first molar is the first tooth in the permanent series that erupts into the archway and thus transforms the temporary dental arcade into mixed arcade, being the only stable element throughout the mixed dentition. The plurivalentimportance of the permanent molar mustbe considered permanently in the harmonious development of the dento apparatus. This tooth has a determining role in dental arcade functionality, being the oldest witness of the permanent occlusion. The permanent first molar is a guardian of the occlusal memory and contributes to the agreement of the predetermined with the posterior one (the temporo-mandibular joint). The first permanent molar improves the relationships in the vertical plane, the early loss of it generates morphological and functional disorders which takes place cascaded across the arcade, and its extraction must be considered a personal failure of the dentist. The study consists of 80 patients divided into two groups; the group I consists of 45 children with chronological ages ranged between 5-6.6 years; the second group selected from dental care, a total of 35 children aged between 8.6-10 years. Dental caries morbidity has increased significantly over time and surprised by age the younger becoming a true social scourge. The current pediatric dentistry emphasizes new aspects of the normal and pathological growth of the dento-maxillary apparatus and underlines the special significance of the morpho-structural and functional integrity of the odontous units in close correlation with the subsequent development of the dento-maxillary apparatus in general.
\end{abstract}

Keywords:permanent primal molar, permanentocclusion, morphological and functional disorder

The permanent molar occupies a special place in the permanent teeth category due to its particular vulnerability to caries, which results in the worsening of all indicators for the entire period of growth [1-10].

Thus, it can be the only tooth injured in children with limited causality. The premature damage to the permanent molar with the compromise of the lateral support zones constitutes an authentic risk factor for the systemic hemostasis of the dento-maxillary apparatus. Early loss of this molar generates morphological and functional disorder that unfolds in cascade throughout the arcade extent - the so-called first permanent molar syndrome .

Among the factors that favour the carioactivity of the first molar permanently and justify the vulnerability of this tooth, we mention:

1. The formation and mineralization of this tooth occurs, at least in part, in the difficult stages of development, i.e. from the moment of birth to the age of three, the frequency of first-year imbalances is responsible for the mineralization disorders of the harsh structures, neonatal of SchoorOrban, which marks the deficiency from the moment of birth, passes to the cracks and occipital dips.

This results in a particular vulnerability of the occlusal face to the dental caries, and structural deficits and hypoplasias may also occur.

2 . The eruption of this tooth is very long, and from the moment it appears under the mucosa until the antagonist encounters the occlusion plan, it takes an average of 6 months to one year, a period that is devoid of functionality. Massive accumulations of bacterial plaque on the occlusal surface would follow.

3. Posterupting is done in difficult conditions because, at least immediately after the eruption, this molar cohabits with caries and mobile milk teeth that favour retention and disfavour self-cleansing.

Therefore, enamel macro- and microdefence does not benefit from salivary repair possibilities.

4. The morphological features of this tooth are also disadvantages that favour the appearance of cavity. These peculiarities are represented by the following main aspects:

- the occlusal face of the lower molar is provided with deep and retentive cracks, and the upper molar with two deep beaks, separated by a strong diagonal ridge; this tooth has the largest occlusal surface;

- the medial face has the second temporar molar a wide contact on the surface that changes disadvantageously after the age of 7 through the intermediate migrations and the closure of the retrocanin space, and after 8 years of age by the cavities and by the mobility of the temporar teeth. All these thus favouring retention and the consequent appearance of pack injuries that are difficult to diagnose and treat;

\footnotetext{
*email: drbuzaturoxana@gmail.com; Phone: 0721236147
} 
- the distal face also becomes subject to retention after the eruption of the second permanent molar with which the contacts are firm for a long time,

- the vestibular face of the molar may be the seat of deep and retentive dips, and the palatinal face at the upper one may present an area the retention in the junction with the Carabelli tuber

- the root growth is accomplished in a long posteruptive period, it takes about four years to reach the final length so that the apex gains the diameter of the teeth mature at the age of 10.

5. The predominance of carbohydrate in the diet at this age, as well as the oral environment with poor oral hygiene, often because hygiene skills at this age are not yet well formed, may be factors that explain the causality of susceptibility.

All these factors explain not only the frequency of dental caries, but also those of pulp complications, and especially that of chronic pulp and gangrene at this tooth. These can be complicated and have the disadvantage that they can stop the growth of the root.

The pathology of the first permanent molar include dental caries, pulp disorders and structural abnormalities.

Thus, abnormalities such as hypoplasia, fluorosis, discromy, acquired or hereditary abnormalities (amelogenesis and imperfect dentinogenesis, dentinal dysplasia, odonto-dysplasias) affects the hard tissues, modifying the coronary anatomy of this tooth.

The permanent prime molar cavity is predominantly occlusal, related to the physiological defects of enamel and dentin. In the case of an immature molar, a particular type of caries, the occlusal ampular cavity. The early detection of this type of caryotic lesion is very important.

However, the permanent first molar may also be the seat of caries that have been evolving and sometimes an average of $0.5 \%$ of lesions on the medial face can be healed if retention conditions disappear as a result of destruction or molar extraction [11-20].

The temporary lesion has a number of peculiarities in relation to the age:

- the permanent premature premolar has early cavities and retains a long-lasting cavity with a change in localization of the lesions, which dictates to the curve a characteristic profile

- the first lesions appear on the occlusal face that remains vulnerable between 6 and 8 years after which the lesions are mainly cantonal on the medial face, and after 12 years with the rash of the second molar there are frequent disturbances on the distal face.

At all stages there is additionally added the possibility of localizations in the pits of the vestibular faces of the lower molars or the vestibular faces of the lower molars or of the palatal faces of the upper molars[20-30].

The different caries at this age stage of the first permanent molar demonstrate the close interrelation between the odontogenetic and morphic peculiarities structural features of this tooth and the aggressiveness of the cariogenic agents, as well as the low defense capacity against the risk factor aggression. The permanent first molar, the problem child of pediatric dentistry (Kuntzel), is the most affected tooth in the permanent series[31-38].

This tooth during the period of growth, and especially the 7-year-old child, is a significant general and dental health problem, which imposes rigorous preventive priorities on prophylactic priorities.

\section{Experimental part}

\section{Material and method}

In the argumentation of the proposed goal, we conducted a clinical and epidemiological study on two samples of subjects during which we monitored the evolution of the first permanent molar in the age range of 5-11 years (first between 5-6.6 years for the first sample, and 8-11 years for the second sample).

\section{Results and discussions}

The transversal epidemiological study was conducted on a group of 45 children within a community with chronological age ranges of 5-6,6 years (pre-school age). In terms of gender distribution, 21 boys and 24 girls.

We have tried to adhere to a working methodology that avoids errors that may occur during examinations and data processing.

We determined: dental caries prevalence indices at this age-global age group and gender distribution, CAO index, severity index and intensity index for the temporary second molar and for the permanent first molar as well as the structure of the teeth affected by gender, and on surfaces in the areas of these molars and differentiated on the two maxillaries.

Although we have dealt with our study of the carioactivity of the first molar, we have also approached the pathology of the temporary molar two given the potential implications of its pathology on the subsequent evolution of the first permanent molar.

After the clinical visual and tactile examination of the subjects, we obtained the following results:

- index of the dental cavity prevalence shows for the group of children the high values both globally ( $86 \%$ ) and gender-differentiated for boys $84.5 \%$ and for girls $88.7 \%$.

- The CAO index has a total value of 3.1 and is genderdifferentiated by 2.5 in boys and by 3.01 in girls, with the female sex being affected predominantly for this age stage. In terms of the CAO index, two arches, the mandibular arcade $(2,2)$ is well ahead of the jaw arcade $(0.9)$.

- The severity index for the temporary second molar illustrates extremely high values, which is an alarm signal. We obtained the overall gravity index with a value of 51.3 and with large differences between the two sexes (girls56.4 , boys-45.7) and between the two jaws (for mandible -63, 51 and for maxilla- 39.18). The differences between the two hemiarcades, right and left, are insignificant (right 50.6 and left 52.02).

- The intensity index for the temporary second molar has a value of 3.62 (global) and differentiated by gender 2.7 at boys and 4.4 girls. The interdental intensity index for the mandible is higher (2.6) than the jaw (1.04).

The structure of the temporary teeth affected at this age is as follows: the largest share has complicated caries (16, 5 in boys and 18, 6 in the girls) and then follows the root remnants (10.5 in the boys and 18.6 in the girls).

Analyzing the structure of the affected teeth on the surfaces we find that for the temporary second molar the occlusal faces are affected. This is motivated by the specific dento-dental stage. While the maxillary molars are affected only by occlusal and distal caries, the mandibles are particularly affected by occlusal caries associated with caries on the mesal and distal faces.

Regarding the permanent first molar, most of the subjects had the molars received in varying degrees of eruption (1,2,3 or 4) and very few of them had molars in contact with the antagonist or completely erupted. 
For these reasons, for the molar one permanent, a gravity index of 2.5 with a higher female prevalence and an intensity index of 1 . was obtained. However, these indices are irrelevant.

If we estimate the coefficient of marbles that is $11.6 \%$, itbecomes relevant, expressing the particular susceptibility to dental caries of this tooth and its vulnerability in the oral environment, closely related to its structural defects as an expression of some disorders either in the intrauterine or postnatal life.

\section{Clinical-epidemiological study on the 8- 11 years.}

The second sample selected from the dental medical care at the request of the Pediatric Clinic, a total of 35 children aged between 8.6-10 years, with a gender distribution: 19 girls and 16 boys.

We would examine 140 permanent molars. The following results were obtained:

- the prevalence index shows a 83\% overall with a higher prevalence of female gender (85.6\%).

- The CAO has a total value of 3.21, with female gender being mainly affected

- the severity index for the definitive first molar is high with 38.4 with large gender differences (43.05\%) compared to the male gender (34.6) .

- Following the carial pattern we notice in the age range 8-9 the predominance of simple occlusal dental caries, deep occlusal caries, while in the age range of 9-11 years are more frequent occlusal-occlusive and occlusal caries lesions, as well as simple deep caries and complicated dental caries.

It is signaled that in the subjects studied by us, about 75$80 \%$ of them presented obtuse-distal dental caries, complicated, non-assembled, at the level of the second permanentmolar, aspect materialized as an imminent risk factor in the occurrence and evolution and the approximate carious lesion of the permanent first molar.

The image illustrated by us is also significant in that it correlates with a low educational level of these children with inadequate food hygiene habits, often with oral or sporadic hygienic skills, inconsistent, misused and misconduct. Thus, the role of pediatric dental health education is particularly important. Pediatric dental health education should aim not only at awakening and keeping in mind the individual's interest in their own health but also the creation of mental behaviours, their practice, manifested by sets of skills capable of ensuring the state of health both in the prophylactic stage and the actual therapeutics.

The permanent first molar produces together with the upper and lower central incisor (the so-called molarincisive tripod) the second elevation of occlusion. Thus, this tooth improves vertical relationships by its eruption force and position it is being able to compensate for vertical imperfections that occur during the rotation of the two maxillaries such a permanent first molar participates in the formation of the Angle occlusion key.

The permanent prime molar is the oldest witness of perpendicular occlusion, being a guardian of the occlusal memory and contributing to the agreement of the previous determinant with the posterior. Shudi considers it the occlusion opener, because of the lower frontal teeth that are its closures. That is why this molar is also called the queen of the chess game which in our case is the genus of the permanent occlusion.

All these elements have a great influence on the subsequent evolution of the dento-maxillary apparatus, considering that the early loss of the primary molar permanent generates morphological and functional disorder, which is cascaded throughout the arcade. The young age of children with dental caries at the level of the definitive first molar, the intellectual demands that children are subjected to in the first years school, the interference of many contagious diseases of childhood, unreal nutrition with abundance of sweets and pasta, the existence of untreated caries in the temporary teeth are only some of the factors that favour the appearance of carious processes acting on the integrity of the permanent first molar. Difficult endodontic treatments, complications which can occur, often make an unrecoverable tooth from the first molar. The premature eruption of this molar is the basis for the occurrence of complex manifestations of postexractional disorders, leading to an occlusal dysfunction.

Often, the carious exclusion of this dental pattern, even in children with limited cariogenicity, unfavourably affect all indicators for almost the entire period of growth.

This particular vulnerability to caries in the primary permanent molar dental pattern demonstrates the close interrelation between particularity of the odontogenetic and morphostructural deviations of this tooth and the aggressiveness of the cariogenic agents, as well as the low defense capacity against the risk factor aggression.

The permanent prime molar remains vulnerable throughout the growth period. In each stage, another face accumulates conditions that favuor both carial attack and the grow th of extremely unfavourable pulp complications, especially until the age of 10. The prerequisite of dental caries in this type of dental during the period of growth and especially in the 7-year- a significant problem of general and dental health, which imposes rigorous preventive priorities. In order to hope for an oro-dental healthy adult population, the application of an oral health programme to this age group when the population is organized in school and preschool colleges, is of major importance.

\section{Conclusions}

If there is a concordance between the bone developmentand the formation of this tooth, the permanent prime molar does not disturb the existing balance of the temporal teeth.

In the case of an insuficient growth of the bone bed or a rhythm too fast of the permanent prime molar to evolve the temporary tooth the connections are disturbing and they will be displaced earlier.

In some cases, premature resorbtions of the roots of the temporar molars two may occur, which will expedite the removal of this tooth from the teeth arch.

The definitive molar one will then behaving as a successional tooth (and not accessory) replacing the temporary second molar and causing either inclusion or ectopic eruption of one of the successive teeth in the supportzone.

Knowing the particularities of growth and general and mental development of children is an absolutely necessary requirement for every dentist working in the pediatric field.

\section{References}

1.AK G, SEPET E, PINAR A, AREN G, TURAN N. Reasons for early loss of primary molars. Oral health. Prev Dent 2005; 3:113- 117.

2.ALAMOUDI N. The prevalence of crowding, attrition, midline discrepancies and premature tooth loss in the primary dentition of children in Jeddah, Saudi Arabia. J Clin Pediatr Dent. 1999; 24(1): 5358. 
3.AL-DASHTI AA, COOK PA, CURZON ME. A comparative study on methods of measuring mesiodistal tooth diameters for interceptive orthodontic space analysis. Eur J Paediatr Dent 2005; 6(2): 97-104.

4.ALSHENEIFI T., HUGHES C.V. Reasons for dentsal extractions in children. Pediatric Dentistry 2001; 23(2): 109-112.

5.*** American Academy of Pediatric Dentistry. Clinical guideline on management of the developing dentition in pediatric dentistry. Pediatr Dent 2004; 26(7): 128-131.

6.BIJ OOR RR, KOHLI K. Contemporary space maintenance for the pediatric patient. N Y State Dent J. 2005; 71(2): 32-35.

7.BISHARA SE, JAKOBSEN JR. Individual variation in tooth-size/ archlength changes from the primary to permanent dentitions. World J Orthod. 2006; 7(2): 145-153. Brill WA. The distal shoe space maintainer chairside fabrication and clinical performance. Pediatr Dent. 2002; 24(6): 561-565.

8.da COSTA CC, ALMEIDA IC, LOCKS A, DA COSTA FILHO LC. Clinical comparative study of the effects of two types of mandibular spaceregaining devices. Gen Dent. 2003; 51(2): 120-6.

9.DANILA I. Dentistica preventiva, Ed. Didactica si Pedagocica, Bucuresti, 2005. Dhindsa A, Pandit I K. Modified Willet's appliance for bilateral loss of multiple deciduous molars: A case report. J Indian Soc Pedod Prevent Dent 2008; 26(3): 132- 135.

10.DURWARD CS. Space maintenance in the primary and mixed dentition. Ann R Australas Coll Dent Surg. 2000; 15:203- 205

11.FARSI NM, ALAMOUDI N. Relationship between premature loss of primary teeth and the development of temporomandibular disorders in children. Int J Paediatr Dent. 2000; 10(1): 57-62

12.FATHIAN M, KENNEDY DB, NOURI MR. Laboratory-made space maintainers:a 7-year retrospective study from private pediatric dental practice. Pediatr Dent 2007; 29(6): 500-506.

13.HORAX S. Fixed space maintainer with molar band in premature loss of primary first molar teeth. J Med Nus 2006; 27(3): 174-176

14.HUTH KC, SAGNER T, HICKEL R. Interdisciplinary rehabilitation and prevention in a case with early and extensive loss of primary teeth. J Clin Pediatr Dent 2002; 26:125-130.

15.KARGUL B, CAGLAR E, KABALAY U. Glass fiber-reinforced composite resin as fixed space maintainers in children: 1- moth clinical follow-up. J Dent Child 2005; 72(3): 109-112.

16.KIRZIOGLU Z, ERTURK MS. Success of reinforced fiber material space maintainers. J Dent Child (Chic). 2004; 71(2): 158-162.

17.KUPIETZKY A. Clinical technique removable appliance therapy for space maintenance following early loss of primary molars. Eur Arch Paediatr Dent 2007; 8(1): 30-34.

18.KUPIETZKY A, TAL E. The transpalatal arch: an alternative to the Nance appliance for space maintenance. Pediatr Dent May-J un 2007; 29(3): 235-238

19.LIN Y, LIN W, LIN YJ . Immediate and six-month space changes after premature loss of a primary maxillary first molar. J. Am Dent Assoc 2007; 138(3): 362-368. Luca Rodica, Pedodonbe, Editura Cerna, Bucuresti, vol. I, II, 2003.

20.MAXIM. A. Dentapia temporara predictor integrativ sistemic al realitatii vietii copilului- o revizuire a literaturii de specialitate. Revista Romana de Medicina Dentara, 2006.

21.MOORE TR, KENNEDY DB. Bilateral space maintainers: a 7- year retrospective study from private practice. Pediatr Dent Nov-Dec 2006; 28(6): 499-505.

22.NAYAK UA, LOIUS J, SAJEEV R, PETER J. Band and loop space maintainer-made easy. J Indian Soc Pedod Prev Dent. 2004; 22(3): 134-136.

23.PADMA KUMARI B, RETNA KUMARI N. Loss of space and changes in the dental arch after premature loss of the lower primary molar: A Iongitudinal study. J Indian Soc Pedod Prev Dent. 2006; 24(2): 90-96. 24.RAJ AB LD. Clinical performance and survival of space maintainers: evaluation over a period of 5 years. ASDC J Dent Child. 2002; 69(2): $156-160,124$.

25.TULUNOGLU 0, ULUSU T, GENC Y. An evaluation of survival of space maintainers: a six-year follow-up study. J Contemp Dent Pract. 2005; 6(1): 74-84
26.TUNISON W, FLORES-MIR C, ELBADRAWY H, NASSAR U, EL-BIALY T. Dental arch space changes following premature loss of primary first molars: a systematic review. Pediatric Dentistry 2008, 30(4): 297302.

27.WASSERSTEIN A, SHALISH M. Adequacy of mandibular premolar position despite early loss of its deciduous molar. ASDC journal of dentistry for children Sep-Dec 2002; 69(3): 254- 258,233-234.

28.BUHACEANU R., LUNGU N.C., , FORNA N.C., et all, Anew Class of Mesoionic4-(1,3-Dithiol-2-ylium) phenolates, Rev.Chim. (Bucharest), 64, no. 8,2013, p.803-807

29.BUHACEANU, R., LUNGU, N.C., FORNA, N.C et all,The Influence of Bromine Substituent on Optical Properties of Some 1,3-Dithiolium Derivatives, Rev.Chim.(Bucharest), 64, no.9,2013, p.960-964

30.COSTAN, A.; DIMA, A.; IONITA, l.; et al., Thermal properties of a TI$6 \mathrm{AL}-4 \mathrm{~V}$ alloy used as dental implant material ,Optoelectronics and Advanced Materials- Rapid Communications, Volume: 5 Issue: 1-2 Pages: $92-95,2011$

31.CHECHERITA, L.E., FORNA, N.C., STAMATIN, O.etal., Correlations between biochemical parameters integrated in stomatognathic system dysfunctional syndrome, Rev.Chim. (Bucharest), 64, no.10, 2013, p. 1172-1181

32..FORNA N, CIMPOESU N; SCUTARIU MM; ET al, Study of the electrocorrosion resistance of titanium alloys used in implantology, Book Group Author(s): IEEE, Conference: 3rd International Conference on E-Health and Bioengineering (EHB) Location: Univ Med \& Pharm, Iasi, ROMANIA Date: NOV 24-26, 2011

33.ANTOHE, M.E., AGOP FORNA, D.,DASCALU,C.G.,FORNA, N.C., The importance of observing the aesthetic requirements in partial edentulous rehabilitation - implications in medical-dental training, International Journal of education and information technologies Volume: 10 p. 199-203, 2016

34.CHECHERITA, L.E., FORNA, NC, SURDU, MACOVEI, A., et al. Influence of chemical therapeutical methods on manducatory muscles, Rev.Chim.(Bucharest), 64, no.11, 2013, p.1312-1316

35.MINCIUNA, M.G., VIZUREANU, P., ACHITEI, D.C.,Structural characterization of some CoCrMo Alloys with medical applications, Rev. Chim. (Bucharest), 65, no. 3, 2014, pg.335-338

36.MANCIUC, C., DOROBAT, C., DANAILA, C., et al., Lymphoma in an HIV-positive patient,Medical surgical journal,119(1), 2015,pg.97-100 37.ANTOHE, M.E., AGOP FORNA, D., DASCALU, C.G., Implications of digital image processing in the paraclinical assessment of the partially edentated patient, Rev.Chim.(Bucharest), 69, no.2,2018, p.521-52 38.COSTEA C.F., TURLIUC M.D., DIMITRIU G.,ET AL., Inflammatory juvenile compound conjunctivalnevi.A.clinicopathological study and literature review,Romanian Journal of morphology and embryology, 58(3),2017, pg.739-747

39.COPCIA, V.E., HRISTODOR, C.M., DUNCA, S., IORDANOVA, R., BACHVAROVA-NEDELCHEVA, FORNA, N.C., SANDU, I., Synthesis and Antibacterial Properties of ZnO/Clinoptilolite and TiO2/ZnTiO3/ Clinoptilolite Pow ders. Rev. Chim. (Bucharest), 64, no.9, 2013, p.978981.

40.POPESCU, E., AGOP FORNA, D., EARAR, K., FORNA, N.C., Bone substitutes used in guided bone regeneration technique review, Mat Plast. 54, no.2, 2017, p. 390-392

41.GURAU, G.,DINU ,C.A., EARAR, K., ,et al, Diagnostic Value of chemical and hematological markers in children acute abdominal pain, Rev.Chim.(Bucharest), 67, no.3,2016, p.507-511

42.STOIAN ,A., EARAR, K.,BUDACU,C.ET AL., No association between antioxidant enzyme gene polymorphism and Albuminuria in Type 2 Diabetes Mellitus Cases, Rev Chim. (Bucharest), 67, no. 11, 2016 43.ANTOHE M.,ANDRONACHE M, FEIER R, STAMATIN O, FORNA NC, Statistical studies regarding therapeutic approaches for edentulous social clinical cases in student, ,spractical stages, Romanian Journal of Oral rehabilitation, 9(2),2017,94-99

44.AGOP FORNA, D., FORNA, N.C., EARAR,K., POPESCU, E., ,Postoperative clinical evolution of edentulous patients treated by guided bone regeneration using xenograft bone substitute and collagen membrane, Mat.Plast., 54, no 2, 2017, p. 312-315 
45.EARAR, K., CERGHIZAN, D., SANDU, A.V., MATEI, M.N., LEATA, R. SANDU, I.G., BEJ INARIU , C., COMAN,M.,. The Role of Functional Polymers in the Optimization of the Acrylic Biomaterials Used in Removable Prosthetic Restoration - II. Assessment of traction test and antifungal activity. Mat.Plast., 52, no 4, 2015, p.487-493

46.CALIN,A.M., DEBITA,M,DRAGOMIR, R., et al.Treatement methods conditioned by the gravity of drug-induced gingival hyperplasias, Rev. Chim.(Bucharest),68, no.11,2017,p.2618-2622

47.MAFTEI,D., ASAFTEI, I.V., SANDU.I., Et al.,Conversion of industrial feedstock mainly with butanes and butenes over HZSM-5 and Zn/ HZSM-5(nitrate)catalysts, Rev.Chim.(Bucharest),66, no 5,2015, p.673680
48.BENEA, H.R., EARAR, K., LATTANZI, W., et al., Collagen scaffold and lipoaspirate fluid - Derived stem cells for the treatment of cartilage defects in a Rabbit Model, Rev.Chim.(Bucharest),69, no 2, 2018, p.515520.

49.EARAR, K., ANTONIAC, V.I., BACIU, S., et al., Etching treatment effect on surface morphology of dental structures, Rev. Chim. (Bucharest), 68, no 11, 2017, p. 2700-2703.

50.GRIGORE,A.M., BUSILA, C., CHESARU, I.B., etal., Biological featurea of tumors results of experimental studies, Rev.Chim.(Bucharest),68, no 3,2017,p, 594-598

$\overline{\text { Manuscript received;21.03.2018 }}$ 